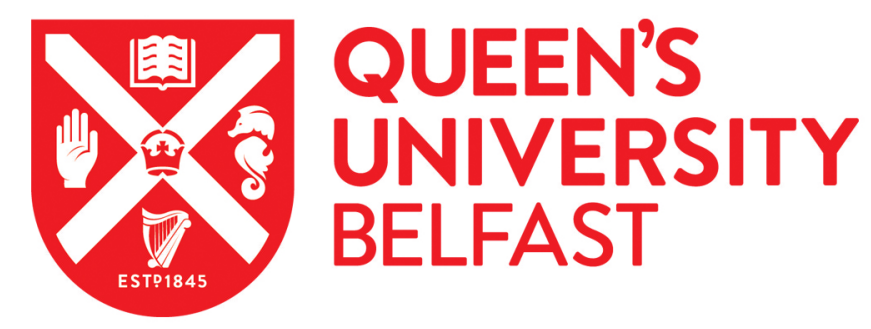

\title{
From Beijing with love: The global dimension of Bertolucci's The Last Emperor
}

Baschiera, S. (2014). From Beijing with love: The global dimension of Bertolucci's The Last Emperor. Journal of Italian Cinema \& Media Studies, 2(3), 399-415. https://doi.org/10.1386/jicms.2.3.399_1

Published in:

Journal of Italian Cinema \& Media Studies

Document Version:

Peer reviewed version

Queen's University Belfast - Research Portal:

Link to publication record in Queen's University Belfast Research Portal

Publisher rights

(c) 2014 Journal of Italian Cinema \& Media Studies

\section{General rights}

Copyright for the publications made accessible via the Queen's University Belfast Research Portal is retained by the author(s) and / or other copyright owners and it is a condition of accessing these publications that users recognise and abide by the legal requirements associated with these rights.

Take down policy

The Research Portal is Queen's institutional repository that provides access to Queen's research output. Every effort has been made to ensure that content in the Research Portal does not infringe any person's rights, or applicable UK laws. If you discover content in the Research Portal that you believe breaches copyright or violates any law, please contact openaccess@qub.ac.uk. 


\title{
From Beijing with love: the global dimension of Bertolucci's The Last Emperor
}

Stefano Baschiera, Queen's University Belfast

DOI 10.1386/jicms.2.3.399_1

Intellect: Journal of Italian Cinema \& Media Studies, Volume 2, Number 3, September 2014, pp. 399-415(17)

\begin{abstract}
Famous for being the first foreign feature film that obtained permission to shoot in the Forbidden City, The Last Emperor (1987) is also one of the most ambitious and expensive independent productions of its time, awarded four Golden Globes and nine Academy Awards, including Best Picture. In addition, The Last Emperor can be considered as one of the first attempts of cinematic collaboration between West and East, in a period of cultural and economic transformations witnessed by China. This paper aims to offer an overview of the production history of The Last Emperor, focusing on the co-production collaborations and the outcomes of a Western auteur's gaze on Chinese history. Questions of Orientalism, travel narrative and critical reception are taken into account in order to engage with the transnational implications of Bertolucci's film and the Western fascination with China.

“末代皇帝”（1987）以第一部获得在紫禁城拍摄的外国故事片而著称。它同时也 是80年代最具雄心和最昂贵的独立电影之一, 荣获了包括最佳电影奖在内的四座金 球奖和九座奥斯卡奖。与此同时，“末代皇帝” 可以被认为是在中国文化和经济 剧变时期最早的东西方电影合作的尝试之一。本文聚焦于联合制片与西方导演对中 国历史的演绎，并旨在论述 “未代皇帝” 制作史的概观。本文通过考虑东方主
\end{abstract}


义, 旅行叙述和电影评论来阐述 Bertolucci电影的跨国界影响和西方对中国的痴

迷。

\section{Keywords}

Bernardo Bertolucci

Co-productions

Film Industry

Film authorship

Travel in cinema

Orientalism

The Last Emperor

\section{Author's biography}

Stefano Baschiera is Lecturer in Film Studies at Queen's University Belfast. His work on European cinema and film industries has been published in a variety of edited collections and journals including Film International, Bianco e Nero, Italian Studies and The New Review of Film and Television Studies. He is writing a monograph on Bertolucci's cinema for Berghahn Books and he is the co-editor with Russ Hunter of the book Italian Horror Cinema forthcoming by Edinburgh University Press.

Stefano Baschiera

Film Studies, 21 University Square 
Queen's University Belfast

Belfast BT7 1NN

UK

s.baschiera@qub.ac.uk

\section{From Beijing with love: the global dimension of Bertolucci's The Last Emperor}

'that's what every tourist agent says to every Italian who goes to China: you will feel like Marco Polo!' (Sklarew and Spitz 1998:49)

On several occasions Bernardo Bertolucci had expressed his desire to shoot Io e Te/Me and You (2012), his most recent film, using 3D technology. Unfortunately, this aspiration was thwarted by budget restrictions, leading the Italian director to make bitter remarks about 3D filmmaking, defining it as 'vulgarly commercial' (Jagernauth 2011).

However, two years later, a 3D version re-release of Bertolucci's The Last Emperor (1987) was presented at the 2013 Cannes Film Festival, at the Cannes Classic Section (Wiseman 2013). This release - which cost two million dollars and took one year of work - not only reiterates the director's enduring fascination with this technology, but also the crucial role that this particular film still plays in Bertolucci's oeuvre, due to its critical success and its global marketing appeal. For instance, film scholar Fabien Gerard - who collaborated as assistant director for The Last Emperor - gives credit to the worldwide dimension of the film arguing that 
the enormity of the undertaking and the unprecedented success of The Last Emperor make this intimate spectacular drama - the most expensive independent European production in the history of the cinema so far - a symbol of the significant relations between China and the West in the middle of the Eighties. (Gerard 1998:65)

Yet its influence has never been reflected at the box office or through its critical reception in China. It is worth noting, in fact, that one of the first goals of Jeremy Thomas, the film's producer, is to ensure a proper theatrical distribution of the $3 \mathrm{D}$ version in China (Geoffrey 2013), an increasingly crucial market that the film never really conquered upon its first release, in spite of the global success and the involvement of the Chinese government in its production. As Thomas stated in a recent interview with The Telegraph,

That film is like Gone with the Wind in China now - it's an ad for the Forbidden City. The time was right. The story's about an emperor who became a citizen, which pleased the government. But no one can shoot in the Forbidden City any more. Still, things are loosening up now. The door's open again. (Gritten 2012)

The aim of this essay is to investigate the global dimension of The Last Emperor, focusing in particular on the role that China played in this independent British, Italian and Chinese co-production, and on its transnational legacy in terms of cinematic exchange between the West and the East. 


\section{An Italo-British-Chinese co-production}

Famous for being the first feature film that obtained permission to shoot in the Forbidden City, (see for instance, McCarthy, among others) ${ }^{1}$ The Last Emperor is also one of the most ambitious and expensive independent productions of its time, awarded four Golden Globes and nine Academy Awards, including Best Picture.

The film is an independent co-production that involved Great Britain, Italy and China. Firmly believing in the project, producer Jeremy Thomas not only managed to acquire the budget from five European merchant banks, but also developed an ambitious relationship with the Chinese Government in order to secure the permission to shoot on location and to ensure the collaboration with Beijing studios. Further to this, it is well known that this was the first Western feature film since 1949 to receive full support from the Chinese government (Dilley 2007: 29).

Thomas recalled how the big Hollywood studios did not want to get involved in a project of such magnitude, which needed to be shot in an unfamiliar country like China. Therefore,

[f]aced with making the film outside the major studio system, Thomas first put up $\$ 400,000$ of his own money to finance the screenplay, the initial trips to China and the employment of artists to make brochures to show potential investors what the film would look like - Imperial China, the Forbidden City.

(Knoedelseder 1988) 
Interestingly, the need for Chinese involvement in the shooting, which was considered to be one of the weaknesses of project by the Hollywood studios, became the main selling point in obtaining financial support from the merchant banks, which were looking for any possibility to create new relationships with the East (Knoedelseder 1988). That was possible in particular once Thomas managed to secure the aforementioned permissions from the Chinese government to host the foreign production for four months. Thomas states that,

[t]hey gave us collaboration on setting up communications, permits, dealing with the army to get 19,000 extras, helping us with research. This is the first (Western) film about modern China, and China is one of the stars of the movie. It was really a \$25-million cultural and business joint venture. (Knoedelseder 1988)

Eventually, the 25 million dollar budget was divided between the five merchant banks: Hill Samuel \& CO in London, Pierson, Gota Banken in Stockholm and Creditanstalt-Bankverein in Vienna, Heldring \& Pierson in Amsterdam, Standard Chartered Bank of London. As reported by Knoedelseder:

Before filming began, much of the risk was covered by $\$ 20$ million in guaranteed distribution agreements for a number of countries. According to Thomas, Hemdale Film Corp. paid a little less than half of the movie's cost for the right to sell the U.S. distribution rights, which eventually went to Columbia Pictures. (Knoedelseder 1988) 
As previously mentioned, the financial gain was not the only reason for the involvement of the banks, which were looking to open up their business to a big country in search of cross-national commercial connections.

In fact, during the post-Cultural Revolution, which began with the death of Mao Zedong in 1976, China embarked in a series of economic reforms under the leadership of Deng Xiaoping. This reform process led to an expansion in commercial and political contacts with the West, leading to the Sino-British Joint Declaration signed in 1984 and which established the return of Hong Kong to China in 1997. Reforms such as the Four Modernisations and the Open Door Policy opened the Chinese market to new foreign trades, representing an important possibility for Western business to develop. Rodney Payne, the head of Hill Samuel's film and television finance division, said that '[w]e figured that any bank which participated in something as important as this film was to them would probably gain extra recognition from authorities. We want to share in the growth of China' (Knoedelseder 1988).

According to Peter Lev, in terms of the film's big budget, it was a daring enterprise as it could not rely on a guaranteed US distributor and it did not feature any particular commercial assets, aside from the United States's fascination with China. In fact,

With a renewal of relations between China and the countries of Europe and North America came a tremendous interest in and enthusiasm for all things Chinese. By the mid-1980s China had become a prestige destination for Western politicians, 
businessmen, experts and tourists. (Lev 1993:118)

Starting from The Last Emperor, China had once again become a viable destination for Western directors. I am thinking, for instance, of Spielberg's Empire of the Sun (1987), which was granted permission by the China Film Co-Production Corporation (CFCC) to shoot for three weeks in Shanghai in 1987, a few months after Bertolucci's crew left Beijing.

For Bertolucci, an independent production was the only feasible way to develop an ambitious international project while maintaining artistic control over the production. The long and difficult production of Novecento/1900 $(1976)^{2}$ led the director to focus on more intimate and relatively low-budget works, leading to the production of films such as La Luna (Luna 1979) and Tragedia di un uomo ridicolo/Tragedy of a Ridiculous Man (1981). Bertolucci's idea for an adaptation of Dashiell Hammet's novel Red Harvest (1927), which he developed for years but never reached the production stage, ${ }^{3}$ was set aside for the occasion to engage with another epic tale - this time setting his sights on the East, on Chinese history. The choice was between two adaptations: Malraux's Man's Fate and the autobiography of the last emperor of China, Pu Yi. As a 1987 article on New York Times recalls:

A trip to China was arranged, and Mr. Bertolucci took along two proposals, André Malraux's 'Man's Fate' and Pu Yi's confession. The Chinese preferred the Pu Yi story. They offered studio facilities and an unlimited supply of extras in return for Chinese distribution and the right to approve the script. (Tonetto 1995) 
According to Thomas, part of the deal included a payment of a few hundred thousand dollars to cover the expenses of the Chinese government. Renouncing the distribution rights in China was not a problem for the producer because, despite the impressive number of movie theatre admissions in China - 25 billion in 1986 (Knoedelseder 1988) the price of a ticket was so low that it made the revenue of that market almost insignificant for a Western production. However, the government's preference for $\mathrm{Pu}$ Yi's story came as a surprise for Bertolucci, who did not grasp how Malraux's work could have negative implications.

Bertolucci, in fact, remembers that the Chinese

at first, $[\ldots]$ they said they didn't know the book, that there was no translation. Finally they admitted that the material was still too touchy. For them, the quarrel between real-life leaders in the strike was still sensitive, and it was a story of the defeat of communism. (Bertolucci 1987:35)

However, once agreed upon the choice of the film, the Chinese government proved to be less exigent than the Hollywood studios in terms of interference with the production and demanding amendments and cuts in the story. According to Bertolucci, after the reading of the script the only changes demanded consisted of the correction of historical inaccuracies (in particular regarding Chinese formalities) and the cut of one particular scene $^{4}$ that was considered too demeaning towards the figure of the Emperor (Koch 2000: 190). 
Chinese participation in the co-production manifested in the project's use of locations and an impressive number of extras, along with the involvement of some Chinese stars of the period. Among the 19,000 extras employed, there were 2,000 soldiers (who agreed to completely shave their heads) and 1,100 film students. However, the language barrier (the film was shot in English) represented a strong limitation to the casting, to the extent that Chinese-American actors (such as Victor Wong in the role of Chen Pao Shen) were employed. ${ }^{5}$ Bertolucci states that:

there are other actors who were not born in China, but generally speaking, I was able to use many native Chinese actors. There is a great deal of Chinese reality in the movie which gave me the confidence to use Chinese-American actors. Let me repeat: I love contaminations, and I love contradictions. (Koch 2000:195)

Interestingly, this love for contradiction and contamination is one of the outcomes of the transnationalism of this co-production, which, as I will discuss later, constantly negotiates between the object of the gaze (Chinese history), the subjectivity behind the camera and the narrative expectations of a Western production.

It is sufficient to think of the somehow difficult 'labelling' of the film, as it goes beyond a national cinematography and even an 'art cinema' label. For instance, the marketing of the film in North America had to rely mostly on the epic story being told, underlining the story's true events, while showing the magnificent locations, settings and extras, as Bertolucci's name was not very marketable and the film did not feature any easily recognisable star with the exception of Irish-British actor Peter O'Toole. 
Among the actors featured in the film, the casting of Joan Chen in the role of the empress is significant as she perfectly embodies the kind of contaminations Bertolucci referred to. In fact, Chen (a graduate from the Shanghai Film Academy) reached star status early in China, thanks to her performance in films such as Xiao hua/ The Little Flower (Xie Jin, 1980), before moving to the US with alternate fortunes. One could argue that she was the only easily recognisable star for the Chinese audience. For Vivian Wu (credited in the film with her Chinese name Wu Jun Mei), instead, the role of Wen Xiu can be considered as the beginning of her career, which eventually developed in the West, with roles in films by Peter Greenaway and Oliver Stone, among others. John Lone, who plays the adult emperor, grew up in Hong Kong and studied acting at the Peking Opera School. Prior to The Last Emperor his film career has been based primarily in the US where he was usually typecast in the generic "East Asian" roles in films such as The Year of the Dragon (Cimino, 1985) and King Kong (Guillermin, 1976).

The participation of the Chinese Government in the project is particularly significant with regard to one piece of casting. The prison governor in the film is played by the actor/director Ying Ruocheng, who was at the time the Chinese vice minister of culture (significantly he had an important role also in Il piccolo Buddha/The Little Buddha (Bertolucci, 1993)).

As we can grasp from the production diary published in France by Gerard (1987), The Last Emperor was shot in twenty-four weeks, between China and Italy, both on location and in studios (Beijing studios and Cinecittà in Rome). The shooting in the Forbidden City meant that the production had to be located in Beijing for sixteen weeks. Sources such as Gerard's work and Bertolucci's interviews offer a significant collection 
of anecdotes regarding the shooting in China, in particular concerning the issue of security to access the Forbidden City and the cultural clashes between Eastern and Western crews, which mainly involved the significant amount of Italian food brought to China for the crew and prepared in an Italian restaurant on the set.

However, what emerges from these recollections of events is the openness towards collaboration and an implicit acknowledgement that the production could have been a milestone in the East/West filmic relationship. ${ }^{6}$ As Thomas underlined in an interview with the Los Angeles Times: 'we had a two-page contract which opens with the statement, in the spirit of friendship and collaboration. It's rather like the Preamble (to the Constitution). There's no first-party-this and second-party-that stuff' (Knoedelseder 1988).

It is impossible to ignore that the production of The Last Emperor and its following international success came in a period when the Chinese directors of the socalled Fifth generation began to create an important bridge between China and the West. I am thinking of directors such as Zhang Junzhao, Zhang Yimou, Chen Kaige and Tian Zhuangzhuang, who graduated from the Beijing Film Academy in the 1980s. From the 1988 Golden Bear awarded to Red Sorghum/Hong gaoliang (Zhang Yimou, 1987) to the Palme D’Or won by Farewell my Concubine/Bawang bie ji (Chen Kaige, 1993) in 1993, films by the Fifth generation directors gathered critical recognition because of their stylistic features and daring plot lines. It is worth noting that Chen Kaige was present on the set of The Last Emperor having been cast as a captain of the Imperial Guard.

It is beyond the scope of this work to draw a comparison between the heterogeneous filmic production of the Fifth Generation and potential similarities with 
The Last Emperor, in particular in the way they address historical themes and the debates surrounding questions of politicisation and commercialisation (Yingjin Zhang 2004: 238). However, as I shall discuss later, it can be assumed that the nine Academy Awards won by The Last Emperor might have helped the distribution in the West of Chinese historical dramas in the late 1980s and early 1990s and overall, the fascination of the West towards China was the mirror of its commercial and political opening.

Before engaging with the impact that Bertolucci's film had in China, it is necessary to properly contextualise The Last Emperor within the director's oeuvre, in order to investigate the transnational impact of the film and its themes.

\section{Bertolucci's travels}

'After Venetian Marco Polo, the Parmegiano [sic] Bertolucci has today become the most Chinese-oriented of Italian travellers'. (Gerard, 1998:165)

While the critical reception of the film focussed mostly on the Chinese settings and story, scholarly works did not fail to notice that The Last Emperor represents an almost ideal continuity of Bertolucci's work, showcasing to a new scale Bertoluccian themes and styles (Lev 1993:118-19; Kline 1998:147-53). I am thinking in particular of its Freudian influences and the representation of sexuality, politics and power. However, one must also consider that the success of The Last Emperor created the opportunity for the financing of his following international productions such as The Sheltering Sky (1990) and later Little Buddha (1993) allowing Bertolucci to engage even more profoundly with 
another (and still understudied) of his recurring themes: travel.

As underlined by Francesco Casetti in the first monograph dedicated to the Italian director (Casetti 1975:18), Bertolucci's films always feature characters in movement, who come and go, to the extent that the idea of journey is deeply embedded in the plot lines. It does not matter if the distance travelled consists in the few kilometres separating Parma from Milan in Prima della rivoluzione/Before the Revolution (1964) or the thousands kilometres journey of the pipe line which carries oil from Persia to Germany, as in the documentary La via del petrolio/Oil (1967). Characters always come and go in Bertolucci's films, stressing a movement and a dislocation which are the essential part of their on-screen identities. The worldwide dimension of Bertolucci's work is also embodied both in his cosmopolitan culture and in the production background of many of his films, featuring international cast, multilingual dialogues and global locations. Significantly, his un-produced film idea Natura contro naturaNature Versus Nature would, according to Bertolucci, have featured three foreign characters talking with different Italian accents for the entirety of the narrative (Bragin 2000: 20).

The concepts of journey and dislocation are present in actions, identity and movements of Bertolucci's characters as well as in the cultural references embodied in his films, in the modes of production and, of course, in the director's biography. The latter, in fact, is characterised by travel and relocations: from Bertolucci's move from Parma to Bologna when he was a child, to his first road trip from Parma to Parigi at nineteen years of age and his own discovery of the pleasure of travelling to discover the ‘unknown' during a trip to Asia in 1973 (Bertolucci 2010: 272-73).

Clearly, The Last Emperor is not Bertolucci's first film to feature an international 
production and cast. At least since Ultimo tango a Parigi/Last Tango in Paris (1972) he managed to secure international funding and a reputation able to cross the national borders. However, The Last Emperor is Bertolucci's first film where the theme of travel embraces both the dimensions of time and space - being set in another continent and focusing on a diachronic epic tale - and where Bertolucci directly engages with a culture that can be defined as 'other' from his. After a series of films deeply intertwined with a European cultural background, Bertolucci looked at East, ideally following into the footsteps of other Italian filmmakers such as Rossellini and Pasolini who aimed to use cinematic devices and narratives in order to explore different and less corrupted realities.

Considering Bertolucci's travel films like The Last Emperor and Sheltering Sky, we can easily grasp how 'in their narratives, spatial exploration is inscribed both in the actions of the mobile protagonists and in the extraordinary ability of the cinematic apparatus to reveal the world' (Eleftheriotis 2010: 76). Bertolucci's filmmaking style, characterised by an expressive cinematography ${ }^{7}$ and camera techniques which reveal histories and spaces through choreographic movements of - and in - the frame, contributed to the aesthetic representation of this other time and space, as well as to a strong positioning of the director's point of view with his luggage of taste and European culture.

In fact, I would argue that Bertolucci's fascination for China, on the one hand, came from his desire to further investigate questions of Marxism and (post)revolution. This desire emerged from Moravia's writings on the Cultural Revolution (Moravia, 1968), which are often referred to by Bertolucci. On the other hand, Bertolucci's fascination can be considered as the result of the curiosity of a cinematic tourist, willing 
to always travel slightly further in order to experience and to reveal a different world, while at the same time, to re-affirm his own cultural identity.

Bertolucci explains his interest in making a film about China's history claiming that he was attracted to it for two reasons:

first of all, the challenge of remaining Italian in China. I think it is a very Italian movie, The Last Emperor. It is very operatic, like Italian opera, and I think it one [sic] of my more Italian movies. The other reason is that I was and I am a bit fed up with reality in my country - even here, everywhere in the West, and so I go looking for a cultural atmosphere which has not been completely invaded and polluted and suffocated and killed by consumerism monoculture. And that's why China is okay. And North Africa, Africa is okay. (Sklarew and Spitz 1998: 49)

Apart from the clear echoes of Pasolini's own choice to look at other continents for his filmmaking in order to escape consumerism (Caminati 2007), ${ }^{8}$ what emerges from Bertolucci's argument is the desire to ideally mingle West and East while acknowledging, at the same time, the inevitability of framing a culture through foreign lenses.

Scholars such as Fatimah Tobing Rony (Rony 1998) and Yosefa Loshitzky (Loshitzky 1995; Loshitzky and Meyuhas 1992) stress the limits of this representation, arguing that The Last Emperor joins Hollywood tradition of colonialist attitude, representing an idealised and stereotyped feminine China. Rony, in particular, affirms that 'The Last Emperor, which after all is a work financed by Western capital, must be 
posited within a tradition of Hollywood realism and the epic film, especially in the ways it reflects Orientalist historiography' (Rony 1998: 143). In particular, she refers to the way the film 'simulates the Hollywood epic film - it is a simulation of a simulation through its self-reflexive style of realism' (Rony 1998: 144). Therefore, the film tends to reduce the complexity of another culture through the narrative construct of the Hollywood genre of the epic film, telling the story bigger than life of the protagonist. Arguably, this kind of criticism can be also adapted to a film like 1900 where the epic film features affect the representation of the Italian historiography, bending it to the genre demands. Analyses of the representation of history in Last Emperor, however, tend to ignore elements of Orientalist historiographies. They focus instead on the understanding of the auteur's approach in terms of his politics and the cinematic medium. Robert Burgoyne, for instance, argues that The Last Emperor presents two dichotomies. The first is a 'Marxist view of historical changes, in which Pu Yi's transformation from Emperor to model citizen is seen as emblematic of the historical order' (Burgoyne 1989: 93). The second consists in 'the production of model images as the fundamental and defining element in the formation of national identity' (Burgoyne 1989: 94), where the cinematic image generates the reality. This happens in the sequence of the screening of the newsreel, which makes Pu Yi confess crimes he did not commit. Burgoyne argues that

[w]ith the complex mediation of the cinematic apparatus placed at the center of the film's discourse about truth, historical actuality, and individual agency, the concept of historical cause is entirely subordinated to the image of history presented in the newsreel. (Burgoyne 1989:98) 
Therefore, Bertolucci not only depicts historical changes of a country, but also attempts to reflect on the role played by moving images in shaping history. Cinema is once again at the center of Bertolucci's representation, stressing in this way the arbitrary gaze of the lenses. In this regard, it is noteworthy that Bertolucci, in 1984, during his first journeys to China in preparation for the film, had a roundtable discussion with Chinese directors (among which Zhang Yimou and Chen Kaige) about their experience of the Cultural Revolution (Bertolucci 2010: 274).

Burgoyne's reflection on the historical agency of the film (through the newsreel) does not engage with The Last Emperor as a Western cultural artefact presenting to a global audience one particular visual representation of the Chinese national identity. Rony, instead, directly engages with the Western-centric characteristic of Bertolucci's lenses stating that,

The Last Emperor's opium-dreamlike oneirism, although self-conscious, descends into old stereotypes about China and Orientalism: that is, Oriental cruelty, sensuality, and lack of rationality. The West has traditionally thought of itself as the site of substance and the Orient as one of surface; the fetishism of the film fro dazzling silks, brocades, and embroidery still promotes an attitude that, after all, underneath the Orient's silky sleeves there is nothing there. (Rony 1998: 144)

The pleasure given from the discovery of new spaces through camera movements and composition further stresses the profilmic focus on the surface. In fact, Bertolucci 'is 
aware of the impossibility of historical authenticity, and thus he highlights the surface of history' (Rony 1998: 144). As it shall be discussed later, the impossibility of the historical authenticity not only is one of the motivations for the attention given to the surface, but it is also the main cultural difference between the reception of the film in the West and in China.

There is only one moment in the film when the camera goes beyond the surface of history, and Rony did not fail to notice it. That happens when 'the horde of Western tourists who invade the Hall of Supreme Harmony reminds us that we too have been tourists in Pu Yi's life' (Rony 1998: 143). This is the first time we spectators enter the Forbidden City after the exile of the Emperor and we can witness the consequences of its opening to the world and to what can be easily foreseen as a capitalistic future. On the one hand the magic belongs to the past, as the cricket, still hidden in the wooden box. On the other hand, mass tourism breaks down the barrier between West and East, mirroring the condition of the film production itself and its relationship with a different culture.

As previously mentioned, Bertolucci was consistently aware of the difficulties of representing another culture through his Western European perspective. As Kaufman reminds, 'Bertolucci is quite preoccupied with the question of the limitations of the cultural lenses' (Kaufman 1998: 21) which are, to some extent, inevitable. Among these limitations there is the inevitable tension between recurring stylistic and thematic features of Bertolucci's filmmaking (what makes him an auteur) and the representation of the cultural past of a country which deeply fascinated the director but that was nevertheless unfamiliar.

In particular, Bertolucci recognises that the cultural differences between East and 
West concern the understanding of the question of individual and collective. Accordingly, the director places this relationship at the centre of the film by focusing on the relationship between subject and society. The latter is, in fact, deeply rooted in Bertolucci's cinema. The protagonists of his films have always to deal with the social impositions, which often derive from class-belonging and legacies deeply rooted with family and State.

From this perspective, The Last Emperor allows Bertolucci to continue this reflection on the role that the environment plays in making history linking the tale of an individual to that of an entire country, in the way he tried already to accomplish with 1900. The education and re-education of $\mathrm{Pu} \mathrm{Yi}$, and his transformation from emperor to citizen are not just an ambiguous statement made by the film towards the emperor reformation and the moral position of Chinese communism, wondering if a man can be perfected. The re-education process embodies the metamorphosis endured by all Bertoluccian characters, struggling with the legacies of their class belonging and the rules of a given society. As Tonetti rightly points out, in The Last Emperor

$\mathrm{Pu} \mathrm{Yi} \mathrm{is} \mathrm{a} \mathrm{foreigner} \mathrm{in} \mathrm{the} \mathrm{land} \mathrm{where} \mathrm{he} \mathrm{should} \mathrm{rule.} \mathrm{He} \mathrm{cannot} \mathrm{see} \mathrm{his} \mathrm{land,} \mathrm{the}$ city of sound, the lively and alive city; he is forced to live in a splendid necropolis ruled by people who have lost, willingly or not, part of their lives (the widows of the former emperor and the eunuchs). (Tonetti 1995: 214)

$\mathrm{Pu} \mathrm{Yi}$ attempts to see beyond the city walls are eventually favoured by another recurring figure in Bertolucci's films: that of the mentor. A clear example of this figure in the 
director's oeuvre is represented by the character of Cesare in Before the Revolution, who is the link between the bourgeois protagonist (Fabrizio) and the world of a socialist revolution he aspires to.

Interestingly, in The Last Emperor the mentoring role is attributed to Reginald Johnston (Peter O'Toole) who, as happened with Cesare, offers to the young pupil a cultural alternative from the world he was born into. Reginald Johnston not only ideally plays the role of mediators between two cultures (the hand shake during their first meeting is the perfect example) and between tradition and modernity (the glasses and the bicycle), he also embodies the foreigner cultural lenses gazing upon China, trying to understand and to embrace it. As such, this figure can be seen as the diegetic representation of the director's approach toward Chinese culture and the attempt of a balance between Bertoluccian features and the historical representations.

\section{The Last EmperorS in China}

'China, more you know it, less you understand it'. (Antonioni in Bertolucci 2010: 274)

Upon its release, The Last Emperor did not meet the same success in China as it did in the Western world, to the extent that, as underlined by Shuyuan Wang and Tiancun Yang, some critics pointed out that the film would not have ever won an award in China (Wang Shuyuan and Yang Tiancun 1989: 76). In fact, in 1988 there was another adaptation of From Emperor to Citizen that became somehow a sensation: the television series Modai 
Huangdi/Last Emperor produced by the China Television Production Centre (which started the scripting in 1981) and transmitted by CCTV (China Central Television). Modai Huangdi popularised the story of $\mathrm{Pu} \mathrm{Yi,} \mathrm{bringing} \mathrm{it} \mathrm{to} \mathrm{Chinese} \mathrm{homes} \mathrm{and,}$ interestingly, it was defined as one of the most accurate historical dramas ever made (Wang \& Yang 1989: 77). It consisted of 28 episodes and won several national awards, including the Chinese Television Flying Apsaras Award for best series and best actor for Chen Daoming.

In the same period that Modai Huangdi was broadcasted on Chinese television, Bertolucci's film was met with scepticism if not completely ignored. As it emerges from Chinese scholarly works of the period, the diffidence towards a film with Chinese actors, story and locations but made by foreign directors and capitals was manifested mainly by pointing out historical inaccuracies, in particular in respect to the television series. The comparison between the two adaptations was recurring in several academic works of the period as a way to engage with two different film aesthetics and (overall) philosophies of historical realism. Articles such as 'The Story of a Chinese King with a Western Director's Style: a Review of Bertolucci's The Last Emperor' (Fan Zhimin 1988), 'The Eastern Historical Tragicomedy and the Western contemporary Humor: Different Aesthetic Standards between East and West in Two The Last Emperor' (Li Li 1989: 8185) and 'Comparison of Two The Last Emperor' (Chen Liao 1988: 65-66), clearly focus their analysis on the differences between the different sensibility toward historical accuracy between the national television production and Western film. Chen Liao (1988), for instance, marks a clear difference between the realist materialism of the television series and the emotional approach of Bertolucci's, stressing a differentiation which recurs 
often in these kinds of analysis.

Haibo Lu, in his analysis of Modai Huangdi, made a reference to Bertolucci's film, arguing that $\mathrm{Pu}$ Yi's story is told by the Italian director in a way to please Western audiences instead of Chinese ones. Lu mentions as example the scene when the emperor sleeps with two women, something that would never happened in the imperial palace (Haibo Lu 1988:146). ${ }^{10}$ Cultural differences and the focus on historical imprecisions emerged again in a 1989 study by Wang Shuyuan and Yang Tiancun. The article aimed to compare the Chinese television series and Bertolucci's film, looking at the reaction of Chinese critics and audiences. The two scholars argue that the Chinese have a different view of the ideas of truth and fiction, taking the faithfulness of the historical representation in more consideration than it is done in Western culture. However, as argued by Wang and Yang, the critics who claim against Bertolucci's The Last Emperor faithfulness need to remember that the director is not an historian and he shot a fiction film rather than a documentary (Wang and Yang 1989: 76).

Interestingly, these arguments stressing the historical mistakes made by Bertolucci, are also at the basis of the only chapter written by Chinese scholars featuring in the edited collection Bertolucci's The Last emperor: Multiple Takes (Sklarew, et al. 1998) entirely dedicated to the analysis of the film. Ding Ning, in fact, in his 1988 essay republished ten years later in the edited collection, stresses how the Chinese value an historical film according to its faithfulness to the facts, demanding a high level of accuracy. For this reason, when watching The Last Emperor the audience was forced to shift and adjust its own experience in order to adapt to the aesthetic challenges raised by this film - one which contains many details that fail to stand up to close scrutiny' (Ding 
Ning 1998: 213-14). Among these mistakes, Ding Ning stresses the inaccurate use of clothes (for instance, those of Ming dynasty, which were forbidden by Qing dynasty) and makeup. Despite these shortcomings, according to Ding Ning, the Chinese appreciated the film for three reasons: first of all, the story of $\mathrm{Pu} \mathrm{Yi}$ is the 'antithesis of the typical 'rags to riches' story characteristic of Western Hollywood narratives, and therefore it makes more sense to the Chinese way of thinking' (Ning 1998: 216). Secondly, because of the location of the Forbidden City and finally for the sexuality of the film as 'Chinese audiences enjoy these lush and erotic sequences, which are more sensual for them than similar scenes in Western PG-rated film, with which it is harder for the Chinese to identify’ (Ning 1998 :216).

Despite the generalisation of Ning's arguments, it is interesting to note the absence of any reference to filmic qualities and aesthetics, both in the positive and negative remarks about Bertolucci's film. A foreign director engaging with a Chinese story and the consequent comparison between Western/Hollywood and national cinema, seem to be the main parameters against which the film was scholarly analysed in China in 1988. The result is therefore significantly different not only from the Western reception mostly dominated by the authorial figure of the director and by the "touristic discovery" of China, as previously discussed - but also in respect to the opening concept which was at the basis of the collaborative production.

It is interesting to note that an authorial approach emerges in these early Chinese criticisms mostly in the attribution of the historical imprecisions to Bertolucci's artistic goals, while there is no mention of the involvement of the Chinese Government in the production and in the approval of the script. On the contrary, this feature was constantly 
underlined by the Western press both to stress an idea of collaboration and the agreement with the facts portrayed. Looking again at the importance of historical accuracy for the Chinese audience, Bonnie Kaufman does not fail to notice that since Ning's essay was written (in 1988) there have been many films from China that 'privilege artistic effects over historical accuracy, and certainly are intelligible to Western audiences as "art films"” (Kaufman, 1998: 31).

However, the scholarly receptions of The Last Emperor in China witnessed a shift in the past decade, distancing their analysis from the historical accuracy and embracing instead the film style and mise en scène. ${ }^{11}$ Recent works, in fact, do not consider any longer the faithfulness of the film as the most important aspect of historical drama, focussing instead on the filmic qualities of the film and contextualising it with the director's oeuvre. For instance, Qu Peng and Zhuang Jun (2012) argue that Bertolucci used visual elements belonging to the Chinese tradition (such as lighting, music, the colour red and symmetrical composition) in order to open foreigners to China. Their paper stresses that The Last Emperor represents the first attempt made by a foreign director to engage directly with Chinese elements.

However, Bai Jingyu and Hu Jixin (2011) look at Bertolucci's depiction of China from under the lenses of Orientalism, in a way not dissimilar to Rony (Rony 1998: 143). Starting from Said's seminal work, the two scholars argue that the Chinese elements featured in the film are there only to meet the exotic expectations of a Western audience, keen to see paper hats, Red Books, Chinese cabbage piled on the side of the street and so on.

While radically different in their approaches to the film, these two articles stress 
the contamination emerging form the meeting between East and West occurring in the film. While previous analysis focused only on matter of historical accuracy, looking at Bertolucci's work from a local perspective, Qu Peng and Zhuang Jun's paper as well as Bai Jinyu and Hu Jixin's place the film within a global context, looking at the interstices between the different Cultures and the director's gaze on China.

\section{Conclusion}

Shot in English in China and Italy by an Italian renowned auteur with English speaking Chinese actors and a lack of easily recognisable stars, The Last Emperor is a big budget independent production which aims to go beyond the box office and artistic merits. This filmic enterprise (mainly financed by European banks) was funded on the possibility of new cultural and business opportunities. The Last Emperor is not easily framed as the typical Hollywood historical drama. This tripartite co-production can be considered, both for its plot and the production history, as one of the first bridges between Western film industry and China, characterised by contamination and contradictions.

In fact, if we look beyond the textual analysis, to the production and reception context of The Last Emperor, we can grasp how the film generated new debates and confrontations in a period of significant changes in Chinese culture and in the relationship East/West, because of the new financial openings. Arguably, the film features two stars, which attracted all the attention and interpretations: Bertolucci and the People's Republic of China.

The former dictated an auteur critical approach and reflections on the role of the director in shaping a foreign historical tale to match his poetics. At the same time, the 
other 'star' - the People's Republic of China - was for the Western audience the main attraction of the film: a new distant world which was opening to foreign visitors and business. From a scholarly perspective the representation of the East was also the further confirmation of a post-colonial Western gaze which reduced the complexity of the 'otherness' to pure surface.

From a Chinese perspective the representation of the country by a foreigner underlined the cultural differences regarding the importance of historical faithfulness and a different conception of artistic values. This changed after the cinematic contaminations between East and West became more common, thanks to the successful distribution to the West of Chinese epical dramas and the films of the Fifth Generation gathered critical appraisals and awards. The contamination between these two stars of the film proves that The Last Emperor goes beyond its art-cinema quality and the box office results. It is a watershed film, not only for Bertolucci's career, but also for the kind of ambitious international independent production aiming to make a bridge across two parts of the world.

\section{References}

Alessi, R. (1986) 'Io, Bertolucci e 60 anni di storia cinese', La Repubblica 7/9

http://ricerca.repubblica.it/repubblica/archivio/repubblica/1986/07/09/io-bertolucci-60anni-di-storia-cinese.html. Accessed 12 September 2013.

Bai J. and Hu J., (2011) 'The Last Emperor from the Orientalism Spectator'. Film Literature, 03, pp.116-117. Original title: 
白晶玉,胡吉星. 东方主义视角下的《末代皇帝》 [J]. 电影文学, 2011 (03), pp. 116117.

Bertolucci, B. Io e Te/Me and You (Fiction Fil, Wildside, Medusa Film, 2012). La Luna/Luna (Fiction Cinematografica S.P.A., 20th Century Fox Film

Corporation, 1979).

Novecento/1900 (PEA, Les Productions Artistes Associés, Artemis Film, 1976).

Il piccolo Buddha/ Little Buddha (Recorded Picture Company, Ciby 2000, Serprocor Anstalt, 1993).

Prima della rivoluzione/Before the Revolution (Cineriz, Iride Cinematografica, 1964).

Il tè nel deserto/The Sheltering Sky (Recorded Picture Company, Warner Bros.

Aldrich Group, Film Trustees Ltd., Sahara Company, TAO Film, 1990).

Tragedia di un uomo ridicolo/Tragedy of a Ridiculous Man (Fiction

Cinematografica SPA, 1981).

L'ultimo Imperatore/The Last Emperor, (Tao Film, Yanco Films, Recorded

Picture Company Productions, Screen Frame, 1987).

La via del petrolio/Oil (Eni, Rai, 1967).

(1987) 'Billions of Emperors', Film Comment, Vol. 23 n 6, p.31, quoted in

Bowker, G. (1988) 'Bertolucci Brings Back Imperial China'. The New York Times

http://www.nytimes.com/packages/html/movies/bestpictures/emperor-ar1.html, Accessed September 2013. 
Bragin, J. (2000), ‘A Conversation with Bernardo Bertolucci', in Gerard, Fabien, Jefferson Kline, and Bruce H. Sklarew (eds.), Bernardo Bertolucci: Interviews (Conversations with Filmmakers), Jackson: University Press of Mississippi, pp. 17-27.

Burgoyne, R. (1989) 'The Last Emperor': the Stages of History'. SubStance 18, no. 2, pp. 93-101.

Caminati, L. (2007) Orientalismo eretico. Pier Paolo Pasolini e il cinema del Terzo Mondo. Milan: Mondadori Bruno.

Casetti, F. (1975) Bernardo Bertolucci. Milan: Il Castoro.

Chen L. (1988) Comparison of Two The Last Emperor. Reality Only, 6, pp.65-66.

Original title: 陈辽. 比较: 两个《末代皇帝》.唯实, 1988(06), pp. 65-66.

Cimino M. The Year of the Dragon (1985).

Dilley W.C. (2007) The Cinema of Ang Lee. London: Wallflower.

Eleftheriotis, D. (2010) Cinematic Journeys: Film and Movement. Edinburgh: Edinburgh University Press. 
Fan Z. (1988) 'The Story of a Chinese King with a Western Director's Style: a Review of Bertolucci's The Last Emperor'. Movie Review, (11), p.17.

Original title: 范志民. 中国皇帝的故事 外国编导的风格

看《末代皇帝》有感. 电影评介. 1988 (11): p. 17.

Geoffrey, M. (2013) 'Details of 3D Last Emperor revealed' Screendaily. http://www.screendaily.com/news/details-of-3d-last-emperor-revealed/5053236.article. Accessed 12 September 2013.

Gerard, Fabien. (1987) Ombres jaunes - journal de tournage Le Dernier Empereur de Bernardo Bertolucci. Paris: Cahiers du Cinéma. (1998) 'The Days of the Dragon'. In Bertolucci's The Last Emperor: Multiple

Takes, Sklarew, B.H. et al. (eds.) Detroit: Wayne State University Press. Pp. 65-84.

Gerard, F., Jefferson K., and Bruce H. S. (eds.) (2000), Bernardo Bertolucci: Interviews (Conversations with Filmmakers), Jackson: University Press of Mississippi.

Gritten, D. (2012) 'The Flowers of War: the Chinese film that is sparking a revolution'. The Telegraph. http://www.telegraph.co.uk/culture/film/9447846/The-Flowers-of-Warthe-Chinese-film-that-is-sparking-a-revolution.html. Accessed 12 September 2013.

Guillermin J. King Kong (1976). 
Jagernauth, K. (2011) 'Bernardo Bertolucci Ditches 3D For His New Movie 'Io e Te' Saying It's 'Vulgarly Commercial' Indiewire, 2011, http://blogs.indiewire.com/theplaylist/bernardo_bertolucci_ditches_3d_for_his_new_mov ie_io_e_te_saying_its_vulgarl. Accessed 12 September 2013.

Kaige C. Farewell my Concubine (1993)

Kaufman, B.S. (1998) 'Introduction'. In Bertolucci's The Last Emperor: Multiple Takes, Sklarew, B.H. et al. (eds.) Detroit: Wayne State University Press, pp. 19-36.

Kline, T.J. (1998) 'The Last Film Director in China: Repetition, Encapsulation, and Transformation in Bertolucci's Cinema'. In Bertolucci's The Last Emperor: Multiple Takes, Sklarew, B.H. et al. (eds.) Detroit: Wayne State University Press, pp.147-172. Knoedelseder, W. K. Jr. (1988) 'Making 'Emperor' in China an Epic Job of Financing'. Los Angeles Times, http://articles.latimes.com/1988-02-01/business/fi-26783_1_modernchina. Accessed 12 September 2013.

Koch, U. (2000) 'Bernardo Bertolucci: Back from China'. In Bernardo Bertolucci: Interviews (Conversations with Filmmakers), in Gerard, F., Kline, J. \& Sklarew, B.H. (eds.) Jackson: University Press of Mississippi.

Lev, P. (1993) The Euro-American cinema. Austin: University of Texas Press. 
Li, L. (1989) 'The Eastern Historical Tragicomedy and the Western contemporary Humor: Different Aesthetic Standards between East and West in Two The Last Emperor'. Modern Communication Journal of Beijing Broadcasting Institute, 01, pp. 8185.

Original title: 李力, 东方的历史悲喜与西方的现代幽默：两部《末代皇帝》的审美视角差异, 现代传播 1989 (01), pp. 81-85.

Liu Y., 'Rereading the Classic: Understanding The Last Emperor', Movie Review, 2009 (23), pp. 26-28.

Original title: 刘永宁. 经典重读:在历史的底色中复现童年-

影片《末代皇帝》读解[J]. 电影评介, 2009, (23), pp. 26-28.

Loshitzky, Y. (1995) The Radical Faces of Godard and Bertolucci. Detroit: Wayne State University Press.

Loshitzky, Y. \& Meyuhas, R. (1992) 'Ecstasy of Difference: Bertolucci’s The Last Emperor'. Cinema Journal, Vol. 31, No. 2, pp. 26-44.

Lu, H. (1988) 'Several Breakthroughs in The Last Emperor'. China Television 06, pp. 146-149.

Original title: 路海波, 《末代皇帝》的几个突破,中外电视, 1988 (06), pp. 146-149. McCarthy, T. (1987) 'Review: The Last Emperor'. Variety, 7 October. http://variety.com/1987/film/reviews/the-last-emperor-1200427361. Accessed 12 September 2013. 
Moravia, A. (1968) The Red book and the Great Wall; an impression of Mao's China. New York: Farrar, Straus \& Giroux.

Ning, Ding. (1998) 'Solving Riddles and Concocting Riddles'. In Bertolucci’s The Last Emperor: Multiple Takes, Sklarew, B.H. et al (eds.) Detroit: Wayne State University Press, pp. 213-222.

Pasolini, P. P. Le mura di Sana'a (The Walls of Sana'a, Rosima Anstalt, 1971).

Qu Peng \& Zhuang Jun (2012) 'China in Foreigner's Eyes: The Audio-visual Art Analysis of The Last Emperor'. Art and Design, 11, pp. 143-145.

Rony, F.T. (1998) The Last Emperor. In Bertolucci's The Last Emperor: Multiple Takes, Sklarew, B.H. et al (eds.) Detroit: Wayne State University Press, pp. 137-146.

Sklarew, B.H. \& Spitz, E.H. (1998) 'Interview with Bernardo Bertolucci'. In Bertolucci's The Last Emperor: Multiple Takes, Sklarew, B.H. et al (eds.) Detroit: Wayne State University Press, pp. 37-54.

Storaro, V. (1998) 'The Story of a Photographic Ideology'. In Bertolucci's The Last Emperor: Multiple Takes, Sklarew, B.H. et al (eds.) Detroit: Wayne State University Press, pp. 57-63. 
Tonetti, M. C. (1995) Bernardo Bertolucci: the Cinema of Ambiguity. London: Twayne Publishers. (2010), La mia magnifica Ossessione - Scritti, ricordi, interventi, Milan:

Garzanti.

Wang S. and Yang T. (1989) Talk about The Last Emperor. Modern Communication, (01), pp. 75-81.

Original title: 王树元,杨田村，《末代皇帝》二人谈，现代传播， 1989 (01), pp. 75-81.

Wiseman, A. (2013), 'Jeremy Thomas, Last Emperor 3D’, Screendaily, 18 May.

http://www.screendaily.com/features/jeremy-thomas-last-emperor-3d/5056260. Accessed

12 September 2013.

Xie J. Xiao hua/ The Little Flower (1980).

Yimou Z. Red Sorghum (1987).

Zhang Y. (2004) Chinese National Cinema New York and London: Routledge. 
${ }^{1}$ Other Western directors secured the permission to access the Forbidden City before The Last Emperor. However, Bertolucci's film was the first fiction feature film to grant access to this location and to be allowed to use it for an extensive period of time.

${ }^{2}$ After four years of troublesome production, Bertolucci had to cut the five hours and a half of the film to a four-hour version for the US market. In fact, only in 1995 a director's cut European version of the film was released in America.

${ }^{3}$ As it emerged from several Bertolucci's interviews (see Gerard, Kline and Sklarew, 2000, in particular pages 149 and 170) the director abandoned the idea of the film adaptation of Red Harvest because of a cultural clash with American studios. In fact, Bertolucci's idea was to place in the foreground the politics of the story focusing on the confrontation between the Liberal and the Marxist characters.

${ }^{4}$ One of the scenes involved the Emperor as a young boy accidentally covered by camel's manure.

${ }^{5}$ Bertolucci made some interesting considerations regarding this particular casting. In an interview, talking about Wong, he notes 'He's a Chinese, and he was looking at the Chinese with American eyes. It would have been very nice to do some video work about all these Chinese-Americans coming to China for the first time, discovering their roots for real' (Koch 2000:194).

${ }^{6}$ The cultural collaboration is strongly stressed by Bertolucci's interviews of the time and by the reportages of Italian newspapers at the time of the production. See for instance Rino Alessi (1986).

${ }^{7}$ On the role played by colors in the narrative of The Last Emperor see Vittorio Storaro (1998:57-61). 
${ }^{8}$ I am thinking, for instance, of the short film Le mura di Sana'a (The Walls of Sana's, Pasolini, 1971).

${ }^{9}$ My translation.

${ }^{10}$ Translations from Chinese have been kindly made for me by Chen Yuanyuan.

${ }^{11}$ See for instance, 'Rereading the Classic: Understanding The Last Emperor' (Liu Yongning 2009). 